\title{
Detection and phylogenetic analysis of infectious pancreatic necrosis virus in Chile
}

\author{
D. Tapia ${ }^{1}$, Y. Eissler* ${ }^{*}$ P. Torres, E. Jorquera, J. C. Espinoza, J. Kuznar \\ Centro de Investigación y Gestión de Recursos Naturales, Instituto de Química y Bioquímica, Facultad de Ciencias, \\ Universidad de Valparaíso, Gran Bretaña 1111, Valparaíso 2360102, Chile
}

\begin{abstract}
Infectious pancreatic necrosis virus (IPNV) is the etiological agent of a highly contagious disease that is endemic to salmon farming in Chile and causes great economic losses to the industry. Here we compared different diagnostic methods to detect IPNV in field samples, including 3 real-time reverse transcription PCR (qRT-PCR) assays, cell culture isolation, and indirect fluorescent antibody test (IFAT). Additionally, we performed a phylogenetic analysis to investigate the genogroups prevailing in Chile, as well as their geographic distribution and virulence. The 3 qRT-PCR assays used primers that targeted regions of the VP2 and VP1 genes of the virus and were tested in 46 samples, presenting a fair agreement within their results. All samples were positive for at least 2 of the qRT-PCR assays, 29 were positive for cell culture, and 23 for IFAT, showing less sensitivity for these latter 2 methods. For the phylogenetic analysis, portions of 1180 and $523 \mathrm{bp}$ of the VP2 region of segment A were amplified by RT-PCR, sequenced and compared with sequences from reference strains and from isolates reported by previous studies carried out in Chile. Most of the sequenced isolates belonged to genogroup 5 (European origin), and 5 were classified within genogroup 1 (American origin). Chilean isolates formed clusters within each of the genogroups found, evidencing a clear differentiation from the reference strains. To our knowledge, this is the most extensive study completed for IPNV in Chile, covering isolates from sea- and freshwater salmon farms and showing a high prevalence of this virus in the country.
\end{abstract}

KEY WORDS: IPNV $\cdot$ Cell culture $\cdot$ Indirect fluorescent antibody test $\cdot$ IFAT $\cdot$ Real-time reverse transcription PCR $\cdot$ qRT-PCR $\cdot$ Diagnostic assays $\cdot$ Phylogeny $\cdot$ VP2 gene

\section{INTRODUCTION}

Infectious pancreatic necrosis (IPN) is a highly contagious disease that affects salmonid fish reared in intensive culture systems, causing high mortality rates in first-feeding fry and in post-smolts shortly after transfer to sea water (Jarp et al. 1995, Evensen \& Santi 2008). IPN is among the most important viral diseases in Chile and is considered endemic in the country, causing great economic losses to the salmon aquaculture industry. Its etiological agent, infectious pancreatic necrosis virus (IPNV), was first isolated in Chile in the 1980s (McAllister \& Reyes 1984, Espinoza et al. 1985), but the presence of IPN was not confirmed until 1998 (Bluth et al. 2003). Since then,

*Corresponding author: yoanna.eissler@uv.cl official reports indicate a broad distribution of the disease and a high incidence in its diagnosis, affecting mainly Atlantic salmon fry (Sernapesca 2007). IPNV is currently one of the most frequently detected pathogens by diagnostic laboratories in both marine and freshwater farms, and the second cause of mortality by infection in adult Atlantic salmon in marine farms in Chile (Sernapesca 2013). Given that IPNV is among the most persistent salmonid pathogens present in the country, there is a need to complete the current information available regarding diagnostic methodologies, distribution of the virus, and types of genogroups present.

Historically, the recommended method for the diagnosis of IPN was based on the isolation of the

() The authors 2015. Open Access under Creative Commons by Attribution Licence. Use, distribution and reproduction are unrestricted. Authors and original publication must be credited.

Publisher: Inter-Research · www.int-res.com 
virus in cell culture, followed by antibody-based identification of the agent (OIE 2006). The need for a more rapid screening procedure for the virus led to the development of faster immunological assays, such as the indirect fluorescent antibody test (IFAT; Espinoza \& Kuznar 2002), and molecular-based techniques such as conventional polymerase chain reaction (PCR) (Blake et al. 1995, Williams et al. 1999, Rodriguez Saint-Jean et al. 2001, Barlic-Maganja et al. 2002). At present, the real-time reverse transcription-PCR (qRT-PCR) method is widely used (Bowers et al. 2008, Ørpetveit et al. 2010, Bowers \& Dhar 2011, Eissler et al. 2011) because its application is simple, accurate, and offers fast results. In Chile, depending on the laboratory, different techniques are used to diagnose IPN, the most common being qRT-PCR and/or IFAT. Additionally, diagnosis of IPN must also rely on the capacity of diagnostic methods to detect the different strains of the virus.

IPNV is a non-enveloped virus that belongs to the family Birnaviridae, genus Aquabirnavirus (Dobos \& Roberts 1983). Its genome holds 2 double-stranded RNA segments: segment A, which encodes a viral capsid protein (VP2), an internal protein (VP3), a viral protease (VP4), and a non-structural protein (VP5); and segment B, which encodes the RNA polymerase (VP1) (Dobos 1995). Aquatic birnaviruses were originally divided into 2 serogroups based on cross-neutralization tests: serogroup A, which contains most of the IPNV isolates associated with the disease grouped into 9 serotypes (A1-A9), and serogroup B, which includes serotype B1 (Hill \& Way 1995). More recently, phylogenetic analysis of the VP2 gene suggested that the 9 strains of serogroup A fall into 6 genogroups that correlated well with serological classification and geographical origin (Blake et al. 2001). The VP2 gene is also considered to play a significant role in virulence, with several amino acid positions identified as possible molecular markers for this characteristic in IPNV strains (Bruslind \& Reno 2000, Santi et al. 2004, Shivappa et al. 2004, Song et al. 2005).

In Chile, the types of IPNV that are present and have been genetically characterized to date belong only to genogroups 1 and 5 (Mutoloki \& Evensen 2011, Eissler et al. 2011, Calleja et al. 2012). However, the geographic zones examined have been limited to very few locations, and the great majority of samples have been from freshwater outbreaks. In order to obtain a broader perspective about the IPNV situation in Chile, a progressive expansion of the geographic areas, host species, and environmental origin sampled is required. In addition, an appropri- ate selection of diagnostic method(s) is necessary for the control of the virus to prevent the escape of IPNV genetic variants that are present in the country.

Accordingly, 2 main objectives were addressed in this work: (1) to examine to which extent current methods used to diagnose IPN in Chile are consistently accurate and reliable as tools to implement control measurements, and (2) to expand the geographic range and source origin of the IPN virus samples in order to increase the knowledge of the genogroups and genotypes prevailing in Chile, as well as their distribution and virulence.

\section{MATERIALS AND METHODS}

\section{Fish samples}

Samples from fry to adults of Atlantic salmon Salmo salar and rainbow trout Oncorhynchus mykiss were collected from different freshwater and seawater fish farms in southern Chile during 2012 and the beginning of 2013 (Table 1). In general, samples were obtained from sites where outbreaks had recently taken place or IPN infection had been diagnosed. Pools of visceral organs (kidney and spleen) containing material usually from 3 fish were stored in L-15 (Leibovitz) medium supplemented with 10\% fetal bovine serum (FBS, HyClone) and $50 \mu \mathrm{g} \mathrm{ml}$ gentamicin, and in parallel in $95 \%$ ethanol. Samples stored in L-15 medium were used for immunofluorescence detection and virus isolation, whereas those stored in $95 \%$ ethanol were used for qRT-PCR assays. The former were homogenized in approximately 5 volumes of L-15 medium, and the latter in phosphate-buffered saline (PBS) $1 \times$ buffer. Both samples were pelleted at $2000 \times g\left(15 \mathrm{~min}\right.$ at $\left.4^{\circ} \mathrm{C}\right)$ in a MIKRO 22R centrifuge (Hettich Zentrifugen). The supernatants were collected and used directly for cell culture inoculation (homogenates in L-15 medium) or for RNA extraction (homogenates in PBS).

\section{Virus isolation in cell culture and immunofluores- cence detection}

For the virus isolation and immunofluorescence assay, Chinook salmon embryo cells (CHSE-214), derived from $O$. tshawtyscha embryonic tissue, were grown as monolayers at $17^{\circ} \mathrm{C}$ in L-15 medium supplemented with $10 \% \mathrm{FBS}$ and $50 \mu \mathrm{g} \mathrm{ml}^{-1}$ gentamicin on 24-well plastic plates with $12 \mathrm{~mm}$ circular glass coverslips, or $33 \mathrm{~mm}$ diameter plastic petri dishes. 


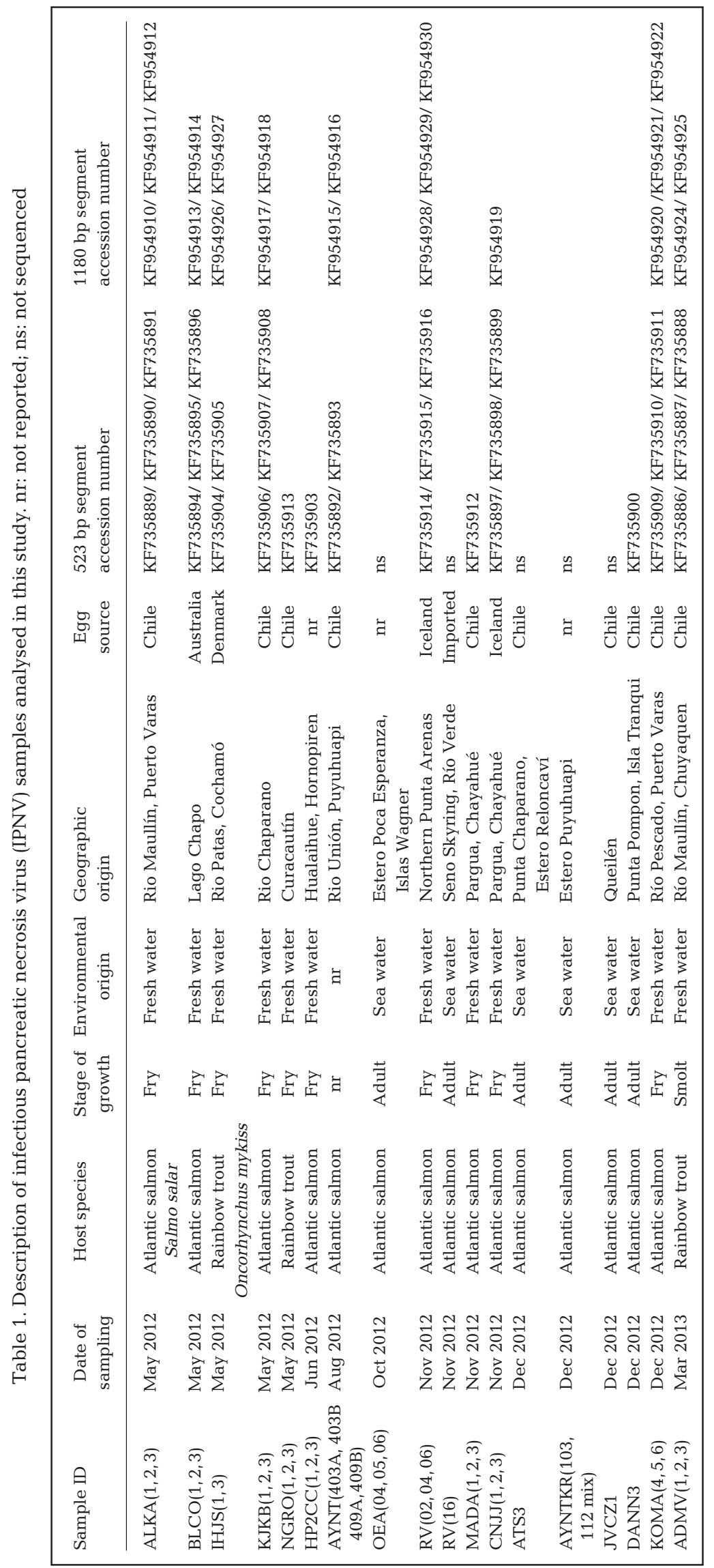

The immunofluorescence assay was done following the methodology described by Espinoza \& Kuznar (2002) with slight modifications. Briefly, cells in the 24-well plastic plates were inoculated with $10 \mu \mathrm{l}$ of the supernatant from the L-15 medium homogenate of the salmonid samples. After $48 \mathrm{~h}$, cell monolayers were fixed with cold methanol for 10 min, rinsed with PBS $1 \times$ buffer, and incubated with a monoclonal antibody (IB3/E10, GrupoBios) against VP2 protein (final concentration: $2 \mu \mathrm{g} \mathrm{m}{ }^{-1}$ ) during $1 \mathrm{~h}$ at room temperature. Cells were rinsed again, and a secondary antimouse antibody (Sigma) conjugated with fluorescein isothiocyanate (FITC) was used to label the infected cells $(1 / 100$ in PBS). Finally, after rinsing the cells for a third time, the circular glass coverslips containing the cell monolayers were mounted on glass slides using an antifade mounting solution (DakoCytomation) and were visualized using an epifluorescence microscope (Olympus BX60).

For virus isolation in cell culture, $20 \mu \mathrm{l}$ of the supernatant from the L-15 medium homogenate were inoculated into CHSE-214 cells, on $33 \mathrm{~mm}$ diameter plastic petri dishes. Cells were incubated at $17^{\circ} \mathrm{C}$ and examined daily for cytopathic effect (CPE) with a light microscope. Cells cultures showing CPE were subjected to 2 cycles of freezing and thawing and were then centrifuged at $3000 \times g\left(15 \mathrm{~min}\right.$ at $\left.4^{\circ} \mathrm{C}\right)$. Supernatants were collected and stored at $-20^{\circ} \mathrm{C}$ until use. If no clear CPE was detected after $7 \mathrm{~d}$ of inoculation, the inoculation process was repeated in a new culture of cells and maintained for another week to ensure development of CPE.

\section{RNA extraction and real-time RT-PCR assays}

Viral RNA from the supernatant of the PBS homogenate of the salmonid samples was extracted according to the manufacturer's instructions with an E.Z.N.A. ${ }^{\text {TM }}$ Total RNA Kit I (Omega Biotek). The extracted RNA was eluted with 
molecular biology grade water and stored at $-80^{\circ} \mathrm{C}$. Concentration and purity of the extracted total RNA was determined by measuring the absorbance ratio at $260 \mathrm{~nm}$ over $280 \mathrm{~nm}$ using a spectrophotometer (Nanodrop ND-1000 UV/VIS). To ensure that contamination remained strictly controlled during the RNA extraction process, a negative control using molecular biology grade water was always included.

The extracted RNA was reverse transcribed and amplified by a 1-step RT-PCR using the Step-One 48well plate real-time PCR system (Applied Biosystems). Three sets of primers designed to detect aquatic birnaviruses were used in the TaqMan ${ }^{\mathrm{TM}}$ and SYBR ${ }^{\circledR}$ green qRT-PCR assays. The first set of primers, VP1F and VP1R, and their appropriate probe, recognize a conserved region within the VP1 gene of segment B (qRT-PCR 1; Eissler et al. 2011); the second set of primers, WB1 and WB2, recognize a 206 bp fragment of the VP2 region of segment A (qRT-PCR 2; Williams et al. 1999); and the third set of primers tested recognize a $164 \mathrm{bp}$ portion of the same region (qRT-PCR 3; Table 2).

The AgPath-ID ${ }^{\text {TM }}$ One-Step RT-PCR Kit (Applied Biosystems) was used for amplification with the first set of primers that recognize segment B of the virus (qRT-PCR 1). This reaction was carried out in a $15 \mu \mathrm{l}$ reaction volume containing $7.5 \mu$ l of RT-PCR Buffer $(2 \times), 0.9 \mu \mathrm{M}$ each of forward and reverse primers, $0.2 \mu \mathrm{M}$ of the VP1 Taqman probe, $0.6 \mu \mathrm{l}$ of RT-PCR Enzyme Mix $(25 \times)$, and $2 \mu \mathrm{l}$ of total RNA. The thermal profile used was $48^{\circ} \mathrm{C}$ for $10 \mathrm{~min}$ for reverse transcription, pre-denaturation at $95^{\circ} \mathrm{C}$ for $10 \mathrm{~min}$; followed by 40 cycles of denaturation at $95^{\circ} \mathrm{C}$ for $15 \mathrm{~s}$ and annealing/extension at $59^{\circ} \mathrm{C}$ for $45 \mathrm{~s}$.
The reaction for the amplification with the sets of primers that recognize segment A of the virus (qRTPCR 2 and 3) was carried out in a $15 \mu \mathrm{l}$ reaction volume containing $7.5 \mu \mathrm{l}$ of $2 \times$ Brilliant III Ultra-Fast SYBR ${ }^{\circledR}$ Green QRT-PCR Master Mix (Stratagene), $0.5 \mu \mathrm{M}$ each of forward and reverse primers, $0.8 \mu \mathrm{l}$ of RT/RNAse block, $0.3 \mu \mathrm{M}$ of ROX as a passive reference, and $2 \mu \mathrm{l}$ of total RNA. The thermal profile used was $50^{\circ} \mathrm{C}$ for $5 \mathrm{~min}$ for reverse transcription, predenaturation at $95^{\circ} \mathrm{C}$ for $3 \mathrm{~min}$; followed by 40 cycles of denaturation at $95^{\circ} \mathrm{C}$ for $5 \mathrm{~s}$ and annealing/extension at $60^{\circ} \mathrm{C}$ for $10 \mathrm{~s}$. Finally, a melting curve analysis from 70 to $95^{\circ} \mathrm{C}$ was performed.

The detection limit, efficiency, and sensitivity of the qRT-PCR assays were evaluated several times using 10-fold dilutions of RNA extracted from a virus reference strain, VUV-84 (Eissler et al. 2011). The amplification efficiency (\%) was calculated based on the formula $\left(10^{(-1 / \text { slope })}-1\right) \times 100$, and varied from 99 to $108 \%$ for all the standard curves performed. The cut-off threshold cycle (Ct) values were 30.8, 32.0, and 32.3, for qRT-PCR 1, 2, and 3, respectively, and the 3 assays were able to detect up to $10^{5}$ dilution, showing the same level of sensitivity.

For each set of samples, all assays were performed on the same day, and a positive control, consisting of the virus strain VUV-84, was always used as a reference sample. No-template controls, consisting of a reaction mixture without template, and negative controls from the RNA extraction were also used in all reactions.

In order to compare the results and evaluate the agreement among the diagnostic methods used, the Kappa statistic was calculated. To assess the

Table 2. Primers and probes used for qRT-PCR assays and sequencing

\begin{tabular}{|c|c|c|c|c|}
\hline $\begin{array}{l}\text { Primers/ } \\
\text { probe }\end{array}$ & Sequence & $\begin{array}{c}\text { Segment: } \\
\text { amplicon position }\end{array}$ & $\begin{array}{l}\text { Amplicon } \\
\text { size (bp) }\end{array}$ & $\begin{array}{l}\text { Coding } \\
\text { region }\end{array}$ \\
\hline \multicolumn{5}{|l|}{ qRT-PCR 1} \\
\hline Probe VP1 & 56FAM-TACATAGGC-ZEN-AAAACCAAAGGAGACAC-IABkFQ & B: $668-820$ & 152 & VP1 \\
\hline VP1F & GTTGATMMASTACACCGGAG & & & \\
\hline VP1R & AGGTCHCKTATGAAGGAGTC & & & \\
\hline \multicolumn{5}{|l|}{ qRT-PCR 2} \\
\hline WB1 & CCGCAACTTACTTGAGATCCATTATGC & A: $139-344$ & 206 & VP2 \\
\hline WB2 & CGTCTGGTTCAGATTCCACCTGTAGTG & & & \\
\hline \multicolumn{5}{|l|}{ qRT-PCR 3} \\
\hline $\mathrm{VP} 2 \mathrm{~F}$ & TCCAACTACGAGCTGATCCC & A: $1227-1390$ & 164 & VP2 \\
\hline VP2R & GTCСТСТССТTGTAСТССТС & & & \\
\hline \multicolumn{5}{|c|}{ For sequencing } \\
\hline $\mathrm{A} 1 \mathrm{~F}$ & TGAGATCCATTATGCTTCCAGA & A: $151-1330$ & 1180 & VP2 \\
\hline $\mathrm{A} 2 \mathrm{R}$ & GACAGGATCATCTTGGCATAGT & & & \\
\hline WB1 & CCGCAACTTACTTGAGATCCATTATGC & A: $139-661$ & 523 & VP2 \\
\hline AIR & GTCTCGTCC TCWAGBCGGACGTATG & & & \\
\hline
\end{tabular}


agreement among the 3 qRT-PCR techniques, a Fleiss Kappa from rating scores was calculated using the online computer program StatsToDo (www. statstodo.com/CohenKappa_Pgm.php); whereas the rest of the Kappa statistics were calculated using GraphPad Software, also available online (http:// graphpad.com/quickcalcs/). The scale used to interpret the Kappa statistic was as follows: <0.01: less than chance agreement; 0.01-0.20: slight agreement; 0.21-0.40: fair agreement; 0.41-0.60: moderate agreement; 0.61-0.80: substantial agreement; and 0.81-0.99: almost perfect agreement (Viera \& Garrett 2005).

\section{RT-PCR amplification and purification of CDNA products for sequencing analysis}

Two fragments of the VP2 gene-coding region were amplified for sequencing, viz. a $1180 \mathrm{bp}$ fragment via conventional PCR and a 523 bp fragment using a nested PCR technique. RNA extractions from viral isolates in cell culture and directly from fish tissue samples were used as templates for the amplification of the $1180 \mathrm{bp}$ fragment, in order to sequence the majority of the positive samples detected for at least 1 of the diagnostic methods used. The product of this amplification was used as template in the second round of amplification for the nested PCR to obtain the $523 \mathrm{bp}$ fragment. This fragment was used to determine the genogroup to which the samples belonged when sequence for the $1180 \mathrm{bp}$ fragment was not obtained. The reactions were carried out using PCR Multigene (Labnet) equipment. First, the fragment of $1180 \mathrm{bp}$ was obtained through RT-PCR as follows: $3 \mu \mathrm{l}$ of viral RNA were mixed with A1F and A2R primers (Table 2, Blake et al. 1995) at a final concentration of $0.5 \mu \mathrm{M}, 10 \mu \mathrm{l}$ of $2 \times$ Brilliant III UltraFast SYBR ${ }^{\circledR}$ Green QRT-PCR Master Mix (Stratagene), $0.8 \mu \mathrm{l}$ of RT/RNAse block, and $4.2 \mu \mathrm{l}$ of the RNase free water in a $20 \mu$ l reaction volume. The conditions for the reaction were $42^{\circ} \mathrm{C}$ for $30 \mathrm{~min}$ for reverse transcription, pre-denaturation at $95^{\circ} \mathrm{C}$ for $3 \mathrm{~min}$; 35 cycles of denaturation at $95^{\circ} \mathrm{C}$ for $30 \mathrm{~s}$, annealing at $58^{\circ} \mathrm{C}$ for $30 \mathrm{~s}$, and extension at $72^{\circ} \mathrm{C}$ for $100 \mathrm{~s}$; and a final extension at $72^{\circ} \mathrm{C}$ for $10 \mathrm{~min}$. Amplified PCR product $(1.5 \mu \mathrm{l})$ was used to carry out the nested PCR using WB1 and AIR primers (Table 2) at a final concentration of $0.5 \mu \mathrm{M}, 15 \mu \mathrm{l}$ of $2 \times$ DreamTaq $^{\mathrm{TM}}$ Green PCR Master Mix (Fermentas), and $10.5 \mu \mathrm{l}$ of the RNase free water in a $30 \mu \mathrm{l}$ reaction volume. The reaction was performed as follows: predenaturation at $95^{\circ} \mathrm{C}$ for $5 \mathrm{~min} ; 35$ cycles of denatura- tion at $95^{\circ} \mathrm{C}$ for $30 \mathrm{~s}$, annealing at $60^{\circ} \mathrm{C}$ for $30 \mathrm{~s}$, and extension at $72^{\circ} \mathrm{C}$ for $45 \mathrm{~s}$; and a final extension at $72^{\circ} \mathrm{C}$ for $10 \mathrm{~min}$.

The amplified fragments resulting from the nested PCR of the expected length were cut out of the gel and transferred to a microcentrifuge tube and purified using a E.Z.N.A. ${ }^{\text {TM }}$ Gel Extraction Kit (Omega Bio-tek), and the PCR products obtained for the 1180 bp fragment were purified using an E.Z.N.A. CYCLE PURE KIT (Omega Bio-tek), following the manufacturer's instructions. The cDNA obtained for each sample was eluted with $55 \mu$ l of molecular biology grade water. Purified duplicates of the PCR products were sequenced by Macrogene (Korea) using an ABI3730XL DNA Analyzer.

\section{Phylogenetic analysis}

The sequences obtained were analysed and compared with reference strains of aquatic birnaviruses and other Chilean IPNV isolates available in GenBank (Blake et al. 2001, Eissler et al. 2011, Mutoloki \& Evensen 2011, Calleja et al. 2012) using the software Bioedit version 7.1.9 (Hall 1999). Multiple sequence alignments were performed using the ClustalW algorithm for sequences of 523 and $1180 \mathrm{bp}$ separately. Phylogenetic trees were constructed for both the 523 and $1180 \mathrm{bp}$ fragment sequences, using the neighbor-joining method with p-distance and 1000 bootstrap replicates with the MEGA 5.22 software (Tamura et al. 2011). The cladogram constructed with the $1180 \mathrm{bp}$ sequences is shown here (see Fig. 1), while the $523 \mathrm{bp}$ cladogram was only used to determine the genogroups in the samples when 1180 bp sequencing was not achieved. In addition, the pairwise distances were calculated for the $1180 \mathrm{bp}$ sequences at the amino acid level to evaluate the degree of sequence similarity. The nucleotide sequences used in this paper were deposited in GenBank, and their respective accession numbers are listed in Table 1.

\section{RESULTS}

During 2012 and the beginning of 2013, a total of 46 field samples of fish organs covering a wide range of geographical locations were processed and analysed to compare different diagnostic methods for IPNV. Table 3 shows the results of 3 qRT-PCR assays, IFAT, and virus isolation in cell culture, according to 
the intensity of their reaction. All samples were positive for at least 2 of the 5 methods tested, and 23 samples $(50 \%)$ were positive for all methods. Of these 23 samples, almost all came from fry; however, no samples from adult fish were positive by all methods. Accordingly, adult fish samples analysed showed the lowest intensity of reactions for all detection methods examined.

\section{Real-time RT-PCR methods}

All fish tissue samples preserved in ethanol were analysed for the detection of IPNV by the qRT-PCR methods described. Positive qRT-PCR amplification was achieved in all 46 samples examined, with a high similarity in the results between the 3 methods, regardless of the differences in the sets of primers

Table 3. Detection of infectious pancreatic necrosis virus (IPNV) in fish organ samples by 5 diagnostic techniques. ns: not sequenced. PCR results are +++: cycle threshold $(\mathrm{Ct}) \leq 20 ;++: \mathrm{Ct} \leq 25 ;+$ : $\mathrm{Ct} \leq 30 ;-$ : negative. Indirect fluorescent antibody test (IFAT) intensity of reaction results are +++: high ++ : medium $_{;}+$: low; - : negative

\begin{tabular}{|c|c|c|c|c|c|c|}
\hline Sample ID & qRT-PCR 1 & qRT-PCR 2 & qRT-PCR 3 & IFAT & Cell culture & Genogroup \\
\hline ALKA1 & +++ & ++ & +++ & ++ & Positive & 5 \\
\hline ALKA2 & +++ & +++ & +++ & ++ & Positive & 5 \\
\hline ALKA3 & +++ & +++ & +++ & +++ & Positive & 5 \\
\hline BLCO1 & +++ & +++ & +++ & + & Positive & 5 \\
\hline BLCO2 & +++ & +++ & +++ & + & Positive & 5 \\
\hline BLCO3 & ++ & + & ++ & ++ & Positive & 5 \\
\hline IHJS1 & ++ & ++ & ++ & - & - & 1 \\
\hline IHJS3 & ++ & +++ & ++ & - & - & 1 \\
\hline KJKB1 & ++ & ++ & +++ & ++ & Positive & 5 \\
\hline KJKB2 & ++ & +++ & +++ & ++ & Positive & 5 \\
\hline KJKB3 & ++ & ++ & +++ & ++ & Positive & 5 \\
\hline NGRO1 & ++ & ++ & + & - & Positive & 5 \\
\hline NGRO2 & ++ & + & + & - & Positive & ns \\
\hline NGRO3 & ++ & + & + & - & Positive & ns \\
\hline $\mathrm{HP} 2 \mathrm{CC} 1$ & +++ & ++ & +++ & +++ & Positive & ns \\
\hline $\mathrm{HP} 2 \mathrm{CC} 2$ & +++ & ++ & +++ & +++ & Positive & ns \\
\hline $\mathrm{HP} 2 \mathrm{CC} 3$ & +++ & +++ & +++ & +++ & Positive & 5 \\
\hline AYNT403A & +++ & +++ & +++ & + & Positive & 5 \\
\hline AYNT403B & +++ & +++ & +++ & + & Positive & ns \\
\hline AYNT409A & +++ & ++ & +++ & + & Positive & ns \\
\hline AYNT409B & ++ & ++ & +++ & + & Positive & 5 \\
\hline OEA04 & + & + & - & - & - & ns \\
\hline OEA05 & + & + & - & - & - & ns \\
\hline OEA06 & + & + & + & - & - & ns \\
\hline RV02 & + & + & + & + & Positive & 5 \\
\hline RV04 & + & + & + & - & Positive & 5 \\
\hline RV06 & +++ & ++ & +++ & +++ & Positive & 5 \\
\hline RV16 & + & + & + & - & - & ns \\
\hline MADA1 & + & + & ++ & - & - & 5 \\
\hline MADA2 & + & + & ++ & - & - & ns \\
\hline MADA3 & + & + & ++ & - & - & ns \\
\hline CNJJ1 & ++ & ++ & + & + & Positive & 5 \\
\hline CNJJ2 & ++ & ++ & + & - & Positive & 5 \\
\hline CNJJ3 & ++ & ++ & + & ++ & Positive & 5 \\
\hline ATS3 & + & + & + & - & - & ns \\
\hline AYNTKR103 & ++ & + & ++ & - & - & ns \\
\hline AYNTKR112 & ++ & + & ++ & - & - & ns \\
\hline AYNTKRmix & ++ & + & ++ & - & - & ns \\
\hline JVCZ1 & + & + & + & - & - & ns \\
\hline DANN3 & ++ & + & + & - & - & 5 \\
\hline KOMA4 & +++ & ++ & +++ & +++ & Positive & 5 \\
\hline KOMA5 & +++ & ++ & +++ & +++ & Positive & 5 \\
\hline KOMA6 & +++ & ++ & +++ & +++ & Positive & 5 \\
\hline ADMV1 & ++ & ++ & ++ & - & - & 1 \\
\hline ADMV2 & ++ & ++ & +++ & - & - & 1 \\
\hline ADMV3 & + & + & + & - & Positive & 1 \\
\hline
\end{tabular}


and chemistries used SYBR ${ }^{\circledR}$ Green and TaqMan ${ }^{\circledR}$ probe (Table 3). Only 2 samples (OEA04, OEA05) were reported negative by 1 of the 3 methods, viz. qRT-PCR 3, probably due to the low viral load of these samples, since the other 2 methods showed high $\mathrm{Ct}$ values. Some differences were found in the intensity of the reactions between the techniques, but in all of the cases, at least 2 of the 3 methods showed results within the same range of $\mathrm{Ct}$ values for the same sample. The Fleiss Kappa analysis indicated a fair agreement between the 3 techniques (Kappa $=0.35)$. All samples from adult fish showed high Ct values (>25) for the 3 assays performed, whereas the majority of the samples from fry showed low Ct values $(<20)$, indicating a higher viral load in samples from younger fish.

\section{IFAT and virus isolation from fish samples}

Virus isolation and IFAT assays were carried out using the fish tissue samples preserved in culture medium. Virus isolation resulted in 29 positive samples showing CPE after 1 or 2 wk of infection in CHSE-214 cells, while analysis by the IFAT assay revealed 23 positive samples after $2 \mathrm{~d}$ of inoculation on cell culture (Table 3 ). Samples positive by IFAT varied in the intensity of the reaction, from highly positive, with many fluorescent cells visualized after the $2 \mathrm{~d}$ of infection, to low intensity in the reaction, with only a few cells showing signs of infection. As expected, all samples that were positive by IFAT also caused CPE on cell culture; nevertheless, 6 samples that showed CPE did not give a positive reaction when assayed by IFAT. When compared by the Kappa statistic, the agreement between virus isolation and IFAT results was considered to be substantial (Kappa $=0.7)$; however, when virus isolation or IFAT were compared to qRT-PCR, there was only a slight agreement (Kappa $=0.14$ and 0.08, respectively).

\section{VP2 gene sequencing}

Results of the VP2 gene sequence comparison revealed 2 distinct genomic groups present in the samples analysed, with $86.2 \%$ similarity between the 2 groups at the amino acid level (data not shown). Phylogenetic analysis revealed that most of the samples (24) were closely related to the reference strain Sp (96.2-97.6\% similarity) belonging to genogroup 5 . Only 5 samples were related to the reference strain
WB (96.8\% similarity) and were thus classified in genogroup 1 according to the genogroups proposed by Blake et al. (2001) (Table 3, Fig. 1). All samples belonging to genogroup 5 were almost identical to (97.1-99.5\% similarity) and clustered together with previously classified Chilean isolates (Eissler et al. 2011, Mutoloki \& Evensen 2011, Calleja et al. 2012), forming a subgroup within the genogroup (Fig. 1). The 5 samples classified in genogroup 1 were clustered in genotype 4 along with the American reference strains $\mathrm{WB}, \mathrm{DM}$, and Ja-ATTC; however, they also formed a subgroup, or subtype, with another Chilean isolate previously classified within this genotype (VCh32523, Calleja et al. 2012) (Fig. 1). Only the first strain of IPNV isolated in Chile (Espinoza et al. 1985; here VUV/84), later classified within genogroup 1, genotype 3 (Eissler et al. 2011), remained separated from the rest of the Chilean isolates clustered in genotype 4.

Regarding geographic distribution, environmental origin, and host species, genogroup 5 was the most widely distributed and was present in all regions examined, in both marine and freshwater farms, in Atlantic salmon as well as in rainbow trout (Fig. 2, Table 1). On the other hand, genogroup 1 was observed only in the Región de Los Lagos (Region X, around $41^{\circ} \mathrm{S}$ ), in freshwater farms from the area of Cochamó and Chuyaquen, and only in rainbow trout.

Table 4 shows the amino acid residues present at the positions identified as major determinants of virulence in the isolates and samples sequenced. Sixteen isolates from genogroup 5 presented threonine at position 217, while the 4 samples from genogroup 1 presented alanine at this position. At the residue 221 , the majority of the isolates from genogroup 5 had alanine, and all of the samples from genogroup 1 presented threonine.

\section{DISCUSSION}

The high persistency and broad distribution of IPN in Chile requires that diagnostic laboratories use reliable and accurate methods for the detection and control of the virus. We compared different diagnostic methods to detect IPNV in field samples from fish in different stages of growth and from both freshwater and marine farms.

Results obtained from the 3 qRT-PCR methods assayed were consistent. Thus these methods were able to detect the virus in all the samples analysed, with no significant differences between the different techniques applied, whether SYBR-Green or Taq- 




man chemistry, nor between the different sets of primers used. To increase the coverage of the diagnostics for American and European genogroups already present in Chile, the primers used in this study were designed to detect aquatic birnaviruses tarGenogroup 1 geting segment A (qRT-PCR 2, Williams et al. 1999; and qRT-PCR 3) or B (qRT-PCR 1, Eissler et al. 2011), in order to incorporate any possible variant of these strains or the emergence of new ones.

As expected, cell culture isolation and IFAT assays showed less sensitivity than qRT-PCR, being able to detect fewer positive samples, but were confirmatory for samples with high titers, and therefore detected the majority of the samples with low $\mathrm{Ct}$ values. This is probably due to the fact that qRT-PCR quantifies the viral nucleic acid present in the sample, without differentiating whether it comes from an active or inactive virus particle. Virus isolation and IFAT, on the other hand, are restricted to the detection of only biologically active viral particles in the sample, i.e. infectious virus. These methods, based on the capacity of the virus to replicate in cell culture, are known to work well in acute cases of the disease, but are less effective in the detection of virus in subclinical or latently infected fish (asymptomatic carriers), where the viral titers can reach their limits of detection (Rodriguez Saint-Jean et al. 2001, Taksdal et al. 2001, Barlic-Maganja et al. 2002, Munro \& Midtlyng 2011). Concordantly, all samples from adult fish (potentially asymptomatic carriers) were below detection levels for cell culture methods but were positive by qRT-PCR, with high Ct values. This is consistent with previous reports which showed that PCR-positive samples from persistently IPNV-infected fish may remain undetected when examined in cell culture (Taksdal et al. 2001, Ørpetveit et al. 2010). In the cases of the

Fig. 1. Phylogenetic tree based on amino acid sequence comparisons of the VP2 gene segment (1180 bp), showing relationships between infectious pancreatic necrosis virus (IPNV) samples analysed in this study (black circles) and reference strains detailed by Blake et al. (2001) and other Chilean isolates (Mutoloki \& Evensen 2011, Calleja et al. 2012). Analyses were conducted using the neighbor-joining method; confidence on tree construction was assessed using 1000 bootstrap replicates 


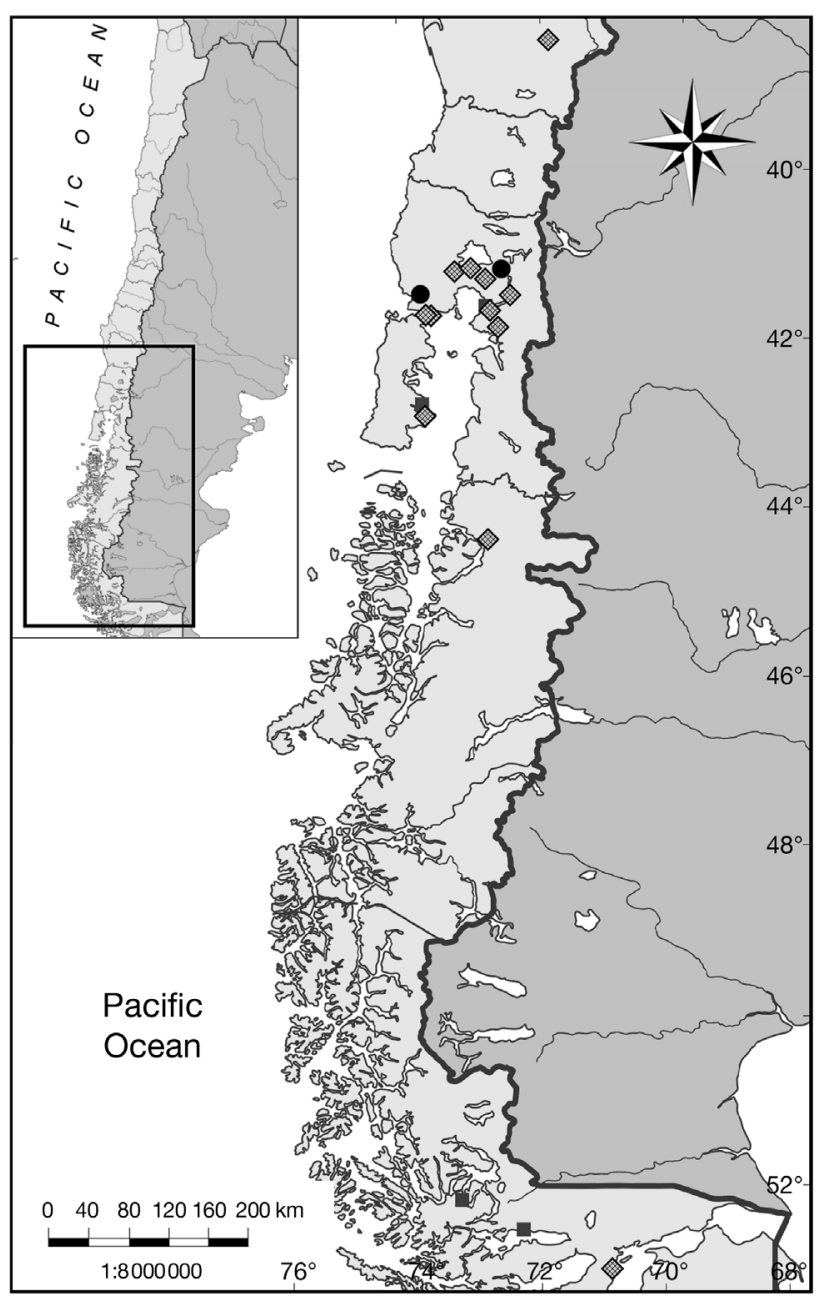

Fig. 2. Distribution of the Chilean infectious pancreatic necrosis virus (IPNV) samples analysed in this study and their corresponding genogroup. Hatched gray diamonds represent viral isolates that belong to genogroup 5, while black circles correspond to genogroup 1. Samples that could not be sequenced are symbolized by grey squares

samples where IFAT was negative but isolation was possible (e.g. NGRO 1-3, RV04, CNJJ2, and ADMV3), an extended time of incubation and greater cell culture area used in the latter method provide a higher probability for active viruses to enter the cells and start their replication cycle, resulting in an increase in the sensitivity of this method, as also considered by Taksdal et al. (2001).

Overall, the results obtained for the diagnostic methods are broadly consistent with other studies which have shown that RT-PCR is the most rapid and sensitive method to detect IPNV, followed by isolation in cell culture and the indirect immunofluorescence technique (Rodriguez Saint-Jean et al. 2001, Taksdal et al. 2001, Barlic-Maganja et al.
2002, Ørpetveit et al. 2010). qRT-PCR is the most common technique used by diagnostic laboratories in Chile to detect the virus. However, laboratories usually do not make public their own in-house methods, probably to attract their clients (salmon industry) with the premise that their method is the best in use. This study shows that, even though there is no standardized molecular methodology for the detection of IPNV, in principle, any of the qRTPCR methods assayed here could be used as a reliable diagnostic technique for the detection of IPNV, in conjunction with cell culture isolation and/or IFAT for confirmation.

The VP2 gene sequencing showed the existence of 2 distinctive genetic groups within the samples analysed, viz. genogroup 5 (European origin) and genogroup 1 (North American origin), as has been previously described for the Chilean IPNV population (Eissler et al. 2011, Mutoloki \& Evensen 2011, Calleja et al. 2012). This is not surprising, since for many years the Chilean salmon industry has imported breeding material from North America and Europe, and a relation between this trade and the transmission of IPNV has already been suggested by Mutoloki \& Evensen (2011). The molecular analysis shows a high degree of similarity between the samples in the genogroups, either European or North American, supporting the thesis of a multiple introduction of different strains of IPNV from these sources throughout the years. However, the phylogenetic tree shows that Chilean viral isolates have slightly differentiated from the original strains that characterized genogroup 1 and 5, to form subgroups or subtypes within each genogroup. This is particularly evident between the Chilean and the North American isolates (WB and DM) within genotype 4, where the clustering of Chilean isolates could suggest the formation of a fifth genotype. Similar tradeassociated transmissions of IPNV have been suggested for isolates from Spain, Japan, Iran, and Ireland, that show a great similarity with reference strains from the sources where these countries have imported salmonid fish and eggs (Cutrín et al. 2004, Nishizawa et al. 2005, Ruane et al. 2009, 2015, Dadar et al. 2013). Concordantly, the phylogenetic trees in these studies also showed grouping among the local isolates and the formation of minor clusters within genogroups. This behavior demonstrates that IPNV, as well as other RNA viruses with high mutation rates, are most likely to form clouds of related mutants, known as quasispecies, rather than individual genomes with the same nucleotide sequence (Domingo et al. 2012). 
Table 4. Amino acid variations in the VP2 region found in Chilean infectious pancreatic necrosis virus (IPNV) isolates. $\mathrm{T}$ : threonine; A: alanine; $\mathrm{S}$ : serine. The virulence motifs were proposed by Song et al. (2005)

\begin{tabular}{|lll|}
\hline \multirow{2}{*}{ Isolate } & \multicolumn{2}{l}{ Amino acid position } \\
& 217 & 221 \\
\hline Genogroup 5 & & \\
ALKA1 & $\mathrm{T}$ & $\mathrm{A}$ \\
ALKA2 & $\mathrm{T}$ & $\mathrm{A}$ \\
ALKA3 & $\mathrm{T}$ & $\mathrm{A}$ \\
BLCO1 & $\mathrm{T}$ & $\mathrm{A}$ \\
BLCO2 & $\mathrm{T}$ & $\mathrm{A}$ \\
AYNT403A & $\mathrm{T}$ & $\mathrm{S}$ \\
AYNT409B & $\mathrm{T}$ & $\mathrm{T}$ \\
KJKB1 & $\mathrm{T}$ & $\mathrm{T}$ \\
KJKB3 & $\mathrm{T}$ & $\mathrm{A}$ \\
CNJJ2 & $\mathrm{T}$ & $\mathrm{A}$ \\
KOMA4 & $\mathrm{T}$ & $\mathrm{A}$ \\
KOMA5 & $\mathrm{T}$ & $\mathrm{A}$ \\
KOMA6 & $\mathrm{T}$ & $\mathrm{A}$ \\
RV02 & $\mathrm{T}$ & $\mathrm{A}$ \\
RV04 & $\mathrm{T}$ & $\mathrm{T}$ \\
RV06 & $\mathrm{T}$ & $\mathrm{A}$ \\
Genogroup 1 & & \\
ADMV1 & $\mathrm{A}$ & $\mathrm{T}$ \\
ADMV2 & $\mathrm{A}$ & $\mathrm{T}$ \\
IHJS1 & $\mathrm{A}$ & $\mathrm{T}$ \\
IHJS3 & $\mathrm{A}$ & $\mathrm{T}$ \\
& & \\
\hline
\end{tabular}

Regarding species-specific association with genogroups, we found that with the exception of NGRO1, all samples from Oncorhynchus mykiss belonged to genogroup 1 and all of the Salmo salar samples belonged to genogroup 5, suggesting a possible relationship between the species and genogroups present in Chile. This is in accordance with the study of Calleja et al. (2012), in which the majority of the isolates of the Sp type (genogroup 5) also came from Atlantic salmon; however, the isolates from the WB type (genogroup) 1 came from rainbow trout, Atlantic salmon, and also Pacific salmon. A larger analysis with more isolates from both genogroups could help in making more conclusive assumptions about host-specific associations with IPNV strains.

In relation to the egg source of the samples, in this study the majority were from Chile, in contrast to previous studies (Mutoloki \& Evensen 2011), where many of the samples from Chile had egg sources from other countries with frequent isolations of IPNV (e.g. Norway, Scotland). These findings demonstrate the endemic character of the virus in the country right now, indicating that IPNV is prevalent in the environment and suggesting that the current transmission of the virus is mainly horizontal. This is sup- ported by the fact that, in an effort to prevent vertical transmission, the only mandatory vigilance program for IPNV in Chile is the screening of breeders, which results in the slaughter of positive breeders and the elimination of their eggs (Sernapesca 2005). Furthermore, the strict standards imposed by the Servicio Nacional de Pesca y Acuicultura (Sernapesca) to prevent the introduction of new pathogens have led to restrictions in the importation of eggs, and the authorization to import only Atlantic salmon eggs from Iceland, a country free of viral diseases (Bravo 2014).

Concerning the geographic distribution of the virus, the majority of the isolates came from the Región de Los Lagos (ca. 41 to $42.5^{\circ} \mathrm{S}$ ), the region with the most salmon farms in Chile. The 2 genogroups identified in the country were present within this region, as one would expect. However, genogroup 5 seems to be the predominant and most widely distributed (i.e. most prevalent), reaching the most austral regions of the country. To our knowledge, this is the most extensive IPNV sampling coverage that has been performed in Chile, both in fresh- and seawater salmon farms. Nonetheless, it is still necessary to cover a higher percentage of salmon farms in order to determine whether genogroup 1 is present at a higher ratio and whether its presence has also extended to the southern part of the country.

Regarding virulence based on molecular characterization, we found that 12 of our isolates (genogroup 5) were classified as highly virulent according to Song et al. (2005), with amino acid residues Thr217/ Ala221. On the other hand, all 4 samples that were classified in genogroup 1, and 3 isolates from genogroup 5, were avirulent by this classification, with threonine in position 221 (Thr221) regardless of the residue in position 217. Nonetheless, all samples from this study came from clinical outbreaks where IPN was diagnosed, and some of the samples with Thr221 showed clear clinical signs of IPN, indicating some inconsistency with the virulence motifs presented by Song et al. (2005). Similarly, Bain et al. (2008) and Ruane et al. (2009) reported that the majority of the isolates in their studies were moderately virulent, with Pro217/Ala221 or avirulent with Thr221; however, when the virulent motifs of these isolates were compared with clinical outbreaks/mortality data, no correlation was found, i.e. clinical outbreaks occurred from isolates with Thr221, and isolates with Pro217/Ala221 showing high virulence based on field and challenge experiment mortality data. Moreover, Song et al. (2005) stated that attenuated strains (i.e. strains with Thr221) are more 
adapted to CHSE-214 cells, thus replicate faster and produce larger plaques, as opposed to what we found in the samples with Thr221 from genogroup 1, which could not be isolated in the cell line and sequencing had to be done directly from the virus present in the tissue sample. Since Song et al. (2005) only worked with isolates from the Sp strain (genogroup 5), these findings suggest that IPNV virulence motifs could differ between genogroups and that other genetics and/or environmental factors may be crucial in determining the outcome of an outbreak of the disease. Mortality data associated with sampling conditions would help correlate virulence motifs to actual virulence patterns for the Chilean IPNV isolates. In addition, experimental challenge studies using recombinant viruses from both genogroups are also needed to identify possible molecular markers of virulence for strains other than Sp.

In conclusion, according to our findings, IPNV seems to be prevalent in Chile, and genogroup 5 appears to be more abundant and widely distributed than genogroup 1, showing the most virulent isolates regarding the previously described amino acids virulence motifs. An apparent relationship between host species and the genogroups was identified; however, to obtain a conclusive answer, more data should be made available. In addition, there is no apparent specific relationship between stage of growth, environmental origin, and the presence of any of these 2 genogroups. Further research is needed to establish whether the genetic variability of IPNV is related to any of these variables or whether other factors are in play. A more extensive number of samples, characterization of outbreaks, and area coverage could help clarify patterns of IPNV strain prevalence and virulence. It is important to point out that Chilean IPN viruses have mutated over time to form genetically differentiated strains. Therefore, the qRT-PCR methods analysed here are suitable to obtain fast and reliable results to diagnose IPN, regardless of the genogroup. To date this is the most extensive study completed on Chilean IPNV isolates with regard to area coverage, number of isolates, molecular analysis, and related epidemiological variables.

Acknowledgements. We gratefully acknowledge the financial support provided by the following grants: Servicio Nacional de Pesca y Acuicultura (Sernapesca) R.E. No. 1090, ‘Estudio evaluación y estandarización de métodos diagnósticos para la determinación del Virus de la Necrosis Pancreática Infecciosa (IPNV)' and Subsecretaría de Pesca y Acuicultura (Subpesca) R.EX No. 1548, código 2013-32-17, 'Identificación de cepas y nuevas variantes de IPNV y evaluación del impacto de éstas en atención a su distribución geográfica y características de cuadros clínicos'.

\section{LITERATURE CITED}

Bain N, Gregory A, Raynard RS (2008) Genetic analysis of infectious pancreatic necrosis virus from Scotland. J Fish Dis 31:37-47

Barlic-Maganja D, Strancar M, Hostnik P, Jencic V, Grom J (2002) Comparison of the efficiency and sensitivity of virus isolation and molecular methods for routine diagnosis of infectious haematopoietic necrosis virus and infectious pancreatic necrosis virus. J Fish Dis 25:73-80

Blake SL, Schill WB, McAllister PE, Lee MK, Singer JT, Nicholson BL (1995) Detection and identification of aquatic birnaviruses by PCR assay. J Clin Microbiol 33: 835-839

> Blake S, Ma JY, Caporale DA, Jairath S, Nicholson BL (2001) Phylogenetic relationships of aquatic birnaviruses based on deduced amino acid sequences of genome segment $\mathrm{A}$ cDNA. Dis Aquat Org 45:89-102

Bluth A, Espinosa L, Guzmán C, Hidalgo C and others (2003) La acuicultura en Chile. Technopress, Santiago de Chile

Bowers RM, Dhar AK (2011) Effect of template on generating a standard curve for absolute quantification of an RNA virus by real-time reverse transcriptase-polymerase chain reaction. Mol Cell Probes 25:60-64

Bowers RM, Lapatra SE, Dhar AK (2008) Detection and quantitation of infectious pancreatic necrosis virus by real-time reverse transcriptase-polymerase chain reaction using lethal and non-lethal tissue sampling. J Virol Methods 147:226-234

Bravo S (2014) Riesgos sanitarios en la importación de ovas. Mundo Acuícola 97:16-17

Bruslind LD, Reno PW (2000) Virulence comparison of three Buhl-subtype isolates of infectious pancreatic necrosis virus in brook trout fry. J Aquat Anim Health 12:301-315

Calleja F, Godoy MG, Cárcamo JG, Bandín I and others (2012) Use of reverse transcription-real time polymerase chain reaction (real time RT-PCR) assays with universal probe library (UPL) probes for the detection and genotyping of infectious pancreatic necrosis virus strains isolated in Chile. J Virol Methods 183:80-85

Cutrín JM, Barja JL, Nicholson BL, Bandín I, Blake S, Dopazo CP (2004) Restriction fragment length polymorphisms and sequence analysis: an approach for genotyping infectious pancreatic necrosis virus reference strains and other aquabirnaviruses isolated from northwestern Spain. Appl Environ Microbiol 70:1059-1067

> Dadar M, Peyghan R, Memari HR, Shapouri MR, Hasanzadeh R, Goudarzi LM, Vakharia VN (2013) Sequence analysis of infectious pancreatic necrosis virus isolated from Iranian reared rainbow trout (Oncorhynchus mykiss) in 2012. Virus Genes 47:574-578

> Dobos P (1995) The molecular biology of infectious pancreatic necrosis virus (IPNV). Annu Rev Fish Dis 5:25-54

Dobos P, Roberts TE (1983) The molecular biology of infectious pancreatic necrosis virus: a review. Can J Microbiol 29:377-384

> Domingo E, Sheldon J, Perales C (2012) Viral quasispecies evolution. Microbiol Mol Biol Rev 76:159-216

Eissler Y, Pavlov MS, Conejeros P, Espinoza JC, Kuznar J (2011) Detection and quantification of Chilean strains of infectious pancreatic necrosis virus by real-time RT-PCR assays using Segment B as a target. Lat Am J Aquat Res 39:544-552

Espinoza JC, Kuznar J (2002) Rapid simultaneous detection and quantitation of infectious pancreatic necrosis virus 
(IPNV). J Virol Methods 105:81-85

Espinoza E, Farias G, Soler M, Juan K (1985) Identity between infectious pancreatic necrosis virus VR-299 and a Chilean isolate. Intervirology 24:58-60

Evensen Ø, Santi N (2008) Infectious pancreatic necrosis virus. In: Mahy BWJ, van Regenmortel MHV (ed) Encyclopedia of virology (3rd edn). Academic Press, Oxford, p 83-89

Hall TA (1999) Bioedit: a user-friendly biological sequence alignment editor and analysis program for Windows 95/98/nt. Nucleic Acids Symp Ser 41:95-98

Hill BJ, Way K (1995) Serological classification of infectious pancreatic necrosis (IPN) virus and other aquatic birnaviruses. Annu Rev Fish Dis 5:55-77

> Jarp J, Gjevre AG, Olsen AB, Bruheim T (1995) Risk-factors for furunculosis, infectious pancreatic necrosis and mortality in post-smolt of Atlantic salmon, Salmo salar L. J Fish Dis 18:67-78

McAllister PE, Reyes X (1984) Infectious pancreatic necrosis virus: isolation from rainbow trout, Salmo gairdneri Richardson, imported into Chile. J Fish Dis 7:319-322

Munro ES, Midtlyng PJ (2011) Infectious pancreatic necrosis and associated aquatic birnaviruses. In: Woo PTK, Bruno DW (eds) Fish diseases and disorders, Vol 3: viral, bacterial and fungal infections, 2nd edn. CABI, Wallingford, p 1-65

Mutoloki S, Evensen O (2011) Sequence similarities of the capsid gene of Chilean and European isolates of infectious pancreatic necrosis virus point towards a common origin. J Gen Virol 92:1721-1726

Nishizawa T, Kinoshita S, Yoshimizu M (2005) An approach for genogrouping of Japanese isolates of aquabirnaviruses in a new genogroup, VII, based on the VP2/NS junction region. J Gen Virol 86:1973-1978

OIE (World Organisation for Animal Health) (2006) Manual of diagnostic tests for aquatic animals. OIE, Paris

Ørpetveit I, Mikalsen AB, Sindre H, Evensen O, Dannevig $\mathrm{BH}$, Midtlyng PJ (2010) Detection of infectious pancreatic necrosis virus in subclinically infected Atlantic salmon by virus isolation in cell culture or real-time reverse transcription polymerase chain reaction: influence of sample preservation and storage. J Vet Diagn Invest 22:886-895

Rodriguez Saint-Jean S, Borrego JJ, Perez-Prieto SI (2001) Comparative evaluation of five serological methods and RT-PCR assay for the detection of IPNV in fish. J Virol Methods 97:23-31

Editorial responsibility: Anindo Choudhury, De Pere, Wisconsin, USA
Ruane NM, McCarthy LJ, Swords D, Henshilwood K (2009) Molecular differentiation of infectious pancreatic necrosis virus isolates from farmed and wild salmonids in Ireland. J Fish Dis 32:979-987

Ruane NM, McCleary SJ, McCarthy LJ, Henshilwood K (2015) Phylogenetic analysis of infectious pancreatic necrosis virus in Ireland reveals the spread of a virulent genogroup 5 subtype previously associated with imports. Arch Virol 160:817-824

Santi N, Vakharia VN, Evensen $\varnothing$ (2004) Identification of putative motifs involved in the virulence of infectious pancreatic necrosis virus. Virology 322:31-40

Sernapesca (Servicio Nacional de Pesca y Acuicultura) (2005) Programa de vigilancia epidemiológica. Norma técnica sección 2. Programas sanitarios generales para peces. Servicio Nacional de Pesca y Acuicultura, Valparaíso

Sernapesca (2007) Informe sanitario de la acuicultura en chile año 2006. Servicio Nacional de Pesca y Acuicultura, Valparaíso

Sernapesca (2013) Informe sanitario de salmonicultura en centros marinos año 2012. Servicio Nacional de Pesca y Acuicultura, Valparaíso

Shivappa RB, Song H, Yao K, Aas-Eng A, Evensen Ø, Vakharia VN (2004) Molecular characterization of Sp serotype strains of infectious pancreatic necrosis virus exhibiting differences in virulence. Dis Aquat Org 61: 23-32

Song H, Santi N, Evensen O, Vakharia VN (2005) Molecular determinants of infectious pancreatic necrosis virus virulence and cell culture adaptation. J Virol 79: 10289-10299

Taksdal T, Dannevig BH, Rimstad E (2001) Detection of infectious pancreatic necrosis (IPN)-virus in experimentally infected Atlantic salmon parr by RT-PCR and cell culture isolation. Bull Eur Assoc Fish Pathol 21:214-219

Tamura K, Peterson D, Peterson N, Stecher G, Nei M, Kumar S (2011) MEGA5: molecular evolutionary genetics analysis using maximum likelihood, evolutionary distance, and maximum parsimony methods. Mol Biol Evol 28: 2731-2739

- Viera AJ, Garrett JM (2005) Understanding interobserver agreement: the kappa statistic. Fam Med 37:360-363

Williams K, Blake S, Sweeney A, Singer JT, Nicholson BL (1999) Multiplex reverse transcriptase PCR assay for simultaneous detection of three fish viruses. J Clin Microbiol 37:4139-4141

Submitted: January 6, 2015; Accepted: August 2, 2015

Proofs received from author(s): October 14, 2015 